\title{
Penyuluhan Pengetahuan Gizi Remaja Pada Siswa SMU Katolik Bintang Laut Kota Ternate Tahun 2021
}

\author{
Andiani ${ }^{1 凶}$, Tutik Lestari ${ }^{1}$, Agustin Rahayu ${ }^{1}$, Diah Merdekawati Surasno ${ }^{1}$, Nani Supriyatni ${ }^{1}$, \\ Monsia A Hi Djafar ${ }^{1}$, dan Musiana ${ }^{1}$
}

1 Mahasiswa Fakultas Ilmu Kesehatan, Universitas Muhammadiyah Maluku Utara. Ternate, Indonesia.

2 Staf Pengajar Fakultas Ilmu Kesehatan, Universitas Muhammadiyah Maluku Utara. Ternate, Indonesia. Email : andianimahbub@gmail.com, tutik198692@gmail.com,agustinyayu21@gmail.com,diah.surasno.86@gmail.com, naniskm@yahoo.com,lovesarichysaray@gmail.com, aryana.elnisa@gmail.com

\footnotetext{
Korespondensi : Andiani, Universitas Muhammadiyah Maluku Utara. Ternate, Indonesia, Email : andianimahbub@gmail.com
}

\begin{abstract}
ABSTRAK
Masalah gizi pada remaja muncul dikarenakan asupan gizi yang belum baik, yaitu ketidakseimbangan antara asupan gizi dengan kecukupan gizi yang dianjurkan. Masalah gizi yang dapat terjadi pada remaja adalah gizi kurang (under weight), obesitas (over weight) dan anemia. Tujuan : Meningkatkan Pengetahuan Gizi Remaja pada Siswa SMU Katolik Bintang Laut Kota Ternate Tahun 2021 Metode: Desain Pengabdian masyarakat ini menggunakan desain pre eksperimental dengan menggunakan pendekatan one group pre-post test design. Tempat di SMA Katolik Bintang Laut Kota Ternate Tahun 2021, jumlah responden penyuluhan sebanyak 49 Responden. Teknik pengambilan sampel pada penelitian ini Purposive sampling. Pengumpulan data dilakukan dengan menggunakan kuesioner. Dari hasil Penyuluhan mengenai Pengetahuan Gizi Remaja pada siswa SMU, setelah dilakukan penyuluhan tingkat Pengetahuan Gizi Remaja ada peningkatan pada responden peserta penyuluhan tertinggi yaitu dengan tingkat pengetahuan baik sebanyak 34 siswa $(69,4 \%)$, sisanya sebanyak 15 siswa (4\%) dengan tingkat pengetahuan kurang. Peningkatan pengetahuan gizi remaja pada peserta penyuluhan yaitu tertinggi pada pertanyaan tentang jenis-jenis sayuran hijau (98\%), Yang temasuk makanan pokok $(95,9 \%)$, masalah gizi pada remaja putri $(95,9 \%)$, Sumber karbohidrat yang dikonsumsi remaja (93,9\%), Yang termasuk dalam lauk hewani $(93,9 \%)$, Tujuan penyususnan menu seimbang bagi remaja $(91,8 \%)$. Ada peningkatan pengetahuan siswa dan siswi SMU Katolik Bintang Laut mengenai pengetahuan gizi remaja sehingga diharapkan kegiatan edukasi pada siswa dan siswi (remaja) dan kerjasama antar lembaga perlu ditingkatkan untuk mencegah permasalahan yang sering dikalangan remaja yaitu kurang gizi, obesitas, pola makan yang salah dan anemia.
\end{abstract}

Keyword: Penyuluhan, Pengetahuan,Gizi, Remaja

\section{PENDAHULUAN}

Menurut WHO (2014), remaja adalah penduduk dalam rentang usia 10-19 tahun,menurut peraturan Mentri Kesehatan RI nomor 25 tahun 2014, remaja adalah penduduk dalam rentang usia 10-18 tahun dan menurut badan kependudukan dan keluarga berencana (BKKBN) rentang usia remaja 10-24 tahun dan belum menikah. Jumlah kelompok usia 10-19 tahun di Indonesia menurut Snesus Penduduk tahun 2010 sebanyak 43,5 juta atau sekitar 18\% dari jumlah penduduk. Di dunia diperkirakan kelompok remaja berjumlah 1,2 milyar atau $18 \%$ dari jumlah penduduk dunia (Kementerian Kesehatan RI, 2017). 
Secara nasional status gizi remaja usia 13-15 tahun dikelompokkan menjadi pendek (Tinggi Badan menurut Umur), dan IMT/U (Indek Massa Tubuh menurut Umur). Prevalensi remaja usia 13-15 tahun yang pendek di Indonesia sebesar 18,5\%, pada umur 16 - 18 Tahun sebesar 22,4\% dan prevalensi kurus pada remaja usia 13-15 tahun sebesar 6,8 \% sedangkan prevalensi gemuk sebesar 11,2 \% (RISKESDAS, 2018). Hasil survei Riskesdas 2013 memperlihatkan bahwa anemia secara umum di Indonesia masih tinggi sebesar 22.7\% pada remaja putri usia 13-18 tahun.

Status gizi yang baik merupakan salah satu penentu kualitas sumber daya manusia (SDM). SDM yang berkualitas dicirikan dengan fisik yang tangguh, mental yang kuat, kesehatan yang prima dan menguasai ilmu pengetahuan serta teknologi. Beberapa indikator yang mengukur tinggi rendahnya kualitas SDM adalah tingkat ekonomi, kesehatan dan pendidikan (Azwar, 2004). Anak yang kekurangan gizi akan mengalami gangguan pertumbuhan fisik, mental dan intelektual. Gangguan tersebut menyebabkan tingginya angka kematian dan kesakitan, serta berkurangnya potensi belajar, daya tahan tubuh dan produktivitas kerja (Soekirman, 2000). Almatsier (2004), status gizi seseorang dipengaruhi oleh makanan yang dikonsumsi. Status gizi baik atau optimal terjadi bila tubuh memperoleh cukup zat-zat gizi yangdigunakan secara efisien.

Remaja rentan mengalami masalah gizi karena merupakan masa peralihan dari masa anakanak ke masa dewasa yang ditandai dengan perubahan fisik fisiologis dan psikososial. Disamping itu kelompok ini berada pada fase pertumbuhan yang pesat (Growth Spurt) sehingga dibutuhkan zat gizi yang relative lebih besar jumlahnya. Gizi pada masa remaja penting sekali untuk diperhatikan, Masa remaja merupakan perubahan dari masa kanak-kanak menuju dewasa. Masa ini terjadi perubahan secara fisik, mental maupun sosial. Hal tersebut menyebabkan permasalahan yang sering terjadi dikalangan remaja putri adalah kurang gizi dan pola makan yang salah (Arisman, 2009).

Masalah gizi dan kesehatan pada masa remaja yaitu gangguan makan, obesitas, anemia, dan makan tidak teratur. Anemia merupakan masalah gizi mikro yang banyak terjadi di Dunia termasuk didalam kelompok berisiko, diantaranya pada anak sekolah. WHO melaporkan 305 juta anak sekolah diseluruh dunia menderita anemia (WHO,2008).

\section{METODE PELAKSANAAN}

Desain Pengabdian masyarakat ini menggunakan desain pre eksperimental dengan menggunakan pendekatan one group pre-post test design. Tempat di SMA Katolik Bintang Laut Kota Ternate Tahun 2021, jumlah responden penyuluhan sebanyak 49 Responden. Teknik pengambilan sampel pada penelitian ini Purposive sampling.

\subsection{Tahap Persiapan}

Pada tahapan ini, diawali dengan kegiatan perizinan untuk melaksanakan kegiatan pengabdian berupa penyuluhan di SMU Katolik Bintang Laut Kota Ternate. Adapun yang dipersiapkan selain surat perizinan, juga persiapan materi dan perlengkapan berupa masker, alat tulis, infokus dan lainnya yang akan digunakan pada saat penyuluhan.

\subsection{Tahap Pelaksanaan}

Pada tahapan pelaksanaan, diawali dengan sambutan dari pihak Sekolah Bintang Laut kemudian pengisian lembar pre-test, setelah itu Kegiatan inti yaitu Penyuluhan dengan tema Pengetahuan Gizi Remaja, diskusi tanya jawab dan diakhiri dengan pengisian lembar post test. Pada akhir penyuluhan, diadakan pembagian suvenir berupa masker dan serta doorprize bagi peserta yang mampu menjawab pertanyaan yang diajukan sebagai umpan balik dari penerimaan materi yang telah disampaikan dalam kegiatan.

\section{HASIL DAN PEMBAHASAN}

Pada Tabel 1 menunjukkan, distribusi responden berdasarkan umur, siswa yang mengikuti penyuluhan pengetahuan gizi pada remaja bervariasi dengan rentang umur $14-18$ tahun, distribusi tertinggi siswa berumur 16 tahun sebanyak 17 siswa $(34,7 \%)$, dan distribusi terendah berumur 18 tahun, sebanyak 3 siswa $(6,1 \%)$. 
Tabel 1. Distribusi Responden Berdasarkan Umur Pengetahuan Gizi Remaja Pada Siswa SMA Katolik Bintang Laut Kota Ternate Tahun 2021

\begin{tabular}{ccc}
\hline $\begin{array}{c}\text { Umur Siswa } \\
\text { (tahun) }\end{array}$ & $\begin{array}{c}\text { Frequency } \\
\text { (n) }\end{array}$ & $\begin{array}{c}\text { Persentase } \\
\text { \% }\end{array}$ \\
\hline 14 & 5 & 10,2 \\
15 & 14 & 28,6 \\
16 & 17 & 34,7 \\
17 & 10 & 20,4 \\
18 & 3 & 6,1 \\
\hline Total & $\mathbf{4 9}$ & $\mathbf{1 0 0}$ \\
\hline
\end{tabular}

Usia subjek dalam penelitian ini berkisar antara 14-18 tahun. Hal tersebut karena anak usia sekolah (14-18 tahun) sudah mulai mengalami proses kematangan seksual, dimana anak perempuan mulai mengalami mensturasi dan juga pertubuhan yang sangat pesar, sehingga membutuhkan zat besi lebih banyak. Perkembangan fungsi-fungsi tubuh juga terganggu karena mengalami perubahanperubahan termasuk perubahan hormonal yang dapat menyebabkan perubahan suasana hati yang tak terduga. Remaja menunjukkan peningkatan reflektivenes tentang diri mereka yang berubah dan meningkat berkenaan dengan apa yang orang pikirkan tentang mereka (Hidayat, 2017).

Tabel 2. Distribusi Responden Berdasarkan Jenis Kelamin Pengetahuan Gizi Remaja Pada Siswa SMA Katolik Bintang Laut Kota Ternate Tahun 2021

\begin{tabular}{lcc}
\hline \multicolumn{1}{c}{ Jenis Kelamin } & $\begin{array}{c}\text { Frequency } \\
\text { (n) }\end{array}$ & Persentase \% \\
\hline Laki-laki & 18 & 36,7 \\
Perempuan & 31 & 63,3 \\
\hline \multicolumn{1}{c}{ Total } & $\mathbf{4 9}$ & $\mathbf{1 0 0}$ \\
\hline
\end{tabular}

Pada Tabel 2 menunjukkan, distribusi responden berdasarkan jenis kelamin, siswa yang mengikuti penyuluhan pengetahuan gizi pada remaja yaitu jenis kelamin teritinggi perempuan sebanyak 31 siswa $(36,7 \%)$ dan sisanya laki-laki berjumlah 18 siswa $(63,3 \%)$.

Tabel 3. Distribusi Responden Berdasarkan Kelas siswa Pengetahuan Gizi Remaja Pada Siswa SMA Katolik Bintang Laut Kota Ternate Tahun 2021

\begin{tabular}{ccc}
\hline Kelas & $\begin{array}{c}\text { Frequency } \\
\text { (n) }\end{array}$ & $\begin{array}{c}\text { Persentase } \\
\text { \% }\end{array}$ \\
\hline X-IPA & 19 & 38,8 \\
XI-IPA & 7 & 14,3 \\
XI-IPS & 2 & 4,1 \\
XII-IPA & 14 & 28,6 \\
XII-IPS & 7 & 14,3 \\
\hline Total & $\mathbf{4 9}$ & $\mathbf{1 0 0}$ \\
\hline
\end{tabular}

Tabel 3 menunjukkan distribusi responden berdasarkan kelas, siswa yang mengikuti penyuluhan pengetahuan gizi pada remaja yaitu terdistribusi mulai dari kelas X sampai XII dengan jurusan IPA dan IPS. Distribusi tertinggi siswa kelas X-IPA berjumlah 19 siswa (38,8\%) dan distribusi terendah kelas XI-IPS berjumlah 2 siswa $(4,1 \%)$.

Tabel 4 menunjukkan Dari hasil Penyuluhan mengenai Pengetahuan Gizi Remaja pada siswa SMU, setelah dilakukan penyuluhan tingkat Pengetahuan Gizi Remaja ada peningkatan pada responden peserta penyuluhan tertinggi yaitu dengan tingkat pengetahuan baik sebanyak 34 siswa $(69,4 \%)$, sisanya sebanyak 15 siswa (4\%) dengan tingkat pengetahuan kurang.

Penelitian ini sejalan dengan penelitian Najahah tahun 2018, terdapat pengaruh penyuluhan gizi seimbang pada remaja terhadap tingkat pengetahuan remaja putri dengan nilai $p=0,000$. (Najahah, 2018). Hasil penelitian (Noviyanti and Marfuah, 2017) adalah status gizi remaja sebagian besar baik dan pengetahuan gizi juga baik. 
Tabel 4. Distribusi Responden Berdasarkan tingkat Pengetahuan Gizi Remaja Pada Siswa SMA Katolik Bintang Laut Kota Ternate Tahun 2021

\begin{tabular}{lcc}
\hline $\begin{array}{c}\text { Tingkat } \\
\text { Pengetahuan }\end{array}$ & $\begin{array}{c}\text { Frequency } \\
\text { (n) }\end{array}$ & $\begin{array}{c}\text { Persentase } \\
\text { \% }\end{array}$ \\
\hline Baik & 34 & 69,4 \\
Kurang & 15 & 30,6 \\
\hline Total & $\mathbf{4 9}$ & $\mathbf{1 0 0}$ \\
\hline
\end{tabular}

Tabel 5. Distribusi Responden Berdasarkan jenis pertanyaan Pengetahuan Gizi Remaja pada Siswa SMA Katolik Bintang Laut Kota Ternate Tahun 2021

\begin{tabular}{|c|c|c|c|c|c|c|c|}
\hline \multirow[t]{2}{*}{ No } & \multirow[t]{2}{*}{ Pertanyaan } & \multicolumn{2}{|c|}{$\begin{array}{c}\text { Jawaban } \\
\text { Benar }\end{array}$} & \multicolumn{2}{|c|}{$\begin{array}{c}\text { Jawaban } \\
\text { Salah }\end{array}$} & \multicolumn{2}{|c|}{ Total } \\
\hline & & $\mathbf{n}$ & $\%$ & $\mathbf{n}$ & $\%$ & $\mathbf{N}$ & $\%$ \\
\hline 1 & $\begin{array}{l}\text { Apa saja yang merupakan masalah gizi } \\
\text { pada remaja putri? }\end{array}$ & 47 & 95.9 & 2 & 4.1 & 49 & 100 \\
\hline 2 & $\begin{array}{l}\text { Apa dampak yang kurang baik, yang akan } \\
\text { terjadi pada remaja yang mengalami } \\
\text { obesitas? }\end{array}$ & 37 & 75,5 & 12 & 25,5 & 49 & 100 \\
\hline 3 & $\begin{array}{l}\text { Pengetahuan tentang gizi di pengaruhi oleh } \\
3 \text { kenyataan yaitu? }\end{array}$ & 40 & 67,3 & 9 & 32,7 & 49 & 100 \\
\hline 4 & $\begin{array}{l}\text { Vitamin yang penting untuk menjaga } \\
\text { jaringan-jaringan baru supaya berfungsi } \\
\text { optimal antara lain? }\end{array}$ & 33 & 67,3 & 16 & 32,7 & 49 & 100 \\
\hline 5 & $\begin{array}{l}\text { Energi dibutuhkan oleh tubuh untuk } \\
\text { mendukung? }\end{array}$ & 45 & 91,8 & 4 & 8,2 & 49 & 100 \\
\hline 6 & Sumber protein yang baik antara lain? & 37 & 75,5 & 12 & 25,5 & 49 & 100 \\
\hline 7 & $\begin{array}{l}\text { Kelebihan asupan lemak akan } \\
\text { menyebabkan? }\end{array}$ & 45 & 91,8 & 4 & 8,2 & 49 & 100 \\
\hline 8 & $\begin{array}{l}\text { Sumber karbohidrat yang dikonsumsi } \\
\text { remaja anatara lain? }\end{array}$ & 46 & 93,9 & 3 & 6,1 & 49 & 100 \\
\hline 9 & $\begin{array}{l}\text { Pada masa remaja kebutuhan mineral } \\
\text { meningkat, mineral berperan penting } \\
\text { untuk? }\end{array}$ & 36 & 73,5 & 13 & 26,5 & 49 & 100 \\
\hline 10 & $\begin{array}{l}\text { Bahan pangan yang mengandung zat besi } \\
\text { berkualitas tinggi adalah? }\end{array}$ & 33 & 67,3 & 16 & 32,7 & 49 & 100 \\
\hline 11 & $\begin{array}{l}\text { Cara meningkatkan kualitas makanan } \\
\text { antara lain dengan? }\end{array}$ & 42 & 85,7 & 7 & 14,3 & 49 & 100 \\
\hline 12 & $\begin{array}{l}\text { Tujuan penyususnan menu seimbang bagi } \\
\text { remaja adalah? }\end{array}$ & 45 & 91,8 & 4 & 8,2 & 49 & 100 \\
\hline 13 & $\begin{array}{l}\text { Faktor-faktor yang mempengaruhi } \\
\text { penyusunan menu seimbang adalah? }\end{array}$ & 29 & 59,2 & 20 & 40,8 & 49 & 100 \\
\hline 14 & $\begin{array}{l}\text { Yang termasuk makanan jenis junkfood } \\
\text { adalah }\end{array}$ & 44 & 89,8 & 5 & 10,2 & 49 & 100 \\
\hline 15 & $\begin{array}{l}\text { Yang termasuk dalam lauk hewani antara } \\
\text { lain }\end{array}$ & 46 & 93,9 & 3 & 6,1 & 49 & 100 \\
\hline 16 & Yang termasuk sayuran hijau antara lain & 48 & 98 & 1 & 2 & 49 & 100 \\
\hline 17 & Yang temasuk makanan pokok antara lain & 47 & 95.9 & 2 & 4.1 & 49 & 100 \\
\hline
\end{tabular}

Tabel 5 menunjukkan Dari hasil Penyuluhan mengenai Pengetahuan Gizi Remaja pada siswa SMU, setelah dilakukan penyuluhan ada peningkatan pengetahuan gizi remaja pada peserta penyuluhan yaitu tertinggi pada pertanyaan tentang jenis-jenis sayuran hijau (98\%), yang temasuk makanan pokok $(95,9 \%)$, masalah gizi pada remaja putri $(95,9 \%)$, Sumber karbohidrat yang dikonsumsi remaja $(93,9 \%)$, Yang termasuk dalam lauk hewani $(93,9 \%)$, Tujuan penyususnan menu seimbang bagi remaja $(91,8 \%)$.

Gizi pada masa remaja meningkat. Kebutuhan zat gizi yang meningkat pada masa remaja adalah energi, protein, kalsium, besi, dan zinc. Asupan energi mempengaruhi pertumbuhan tubuh dan 
bila asupan tidak adekuat menyebabkan seluruh unit fungsional remaja ikut menderita, antar lain derajat metabolisme, tingkat aktivitas, tampilan fisik dan maturitas organ seksual (Sya`Bani dan Sumarmi, 2016).

\section{PENUTUP}

Ada peningkatan pengetahuan siswa dan siswi SMU Katolik Bintang Laut mengenai pengetahuan gizi remaja, sehingga diharapkan kegiatan edukasi pada siswa dan siswi (remaja) dan kerjasama antar lembaga perlu ditingkatkan untuk mencegah permasalahan yang sering dikalangan remaja yaitu kurang gizi, obesitas, pola makan yang salah dan anemia.

\section{DAFTAR PUSTAKA}

Almatsier, S. 2004. Prinsip Dasar Ilmu Gizi. Jakarta: Penerbit PT. Gramedia Pustaka Utama. Arisman. 2009. Buku Ajaran Ilmu Gizi: Gizi Dalam Daur Kehidupan. Jakarta : Penerbit ECG.

Hidayat R. 2017. Hak Atas derajat pelayanan kesehatan yang optimal. Syariah Jurnal Hukum dan Pemikiran, 16(2): 127. doi: 10.18592/sy.v16i2.1035.

Kementerian Kesehatan RI. 2017. "Infodatin Reproduksi Remaja-Ed.Pdf." Situasi Kesehatan Reproduksi Remaja (Remaja): 1-8.

Najahah, Imtihanatun. 2018. "Pengaruh Penyuluhan Gizi Seimbang Pada Remaja Putri Terhadap Tingkat Pengetahuan Remaja Putri Di Pondok Pesantren Islam Nw Penimbung." 12(10): 467-74.

Noviyanti, Retno Dewi, \& Dewi Marfuah. 2017. "Hubungan Pengetahuan Gizi, Aktivitas Fisk, Dan Pola Makan Terhadap Status Gizi Remaja Di Kelurahan Purwosari Laweyan Surakarta." University Research Colloquium: 421-26.

RISKESDAS, Nasional Badan Penelitian dan Pengembangan. 2018. “Laporan_Nasional_RKD2018_ FINAL.Pdf." Badan Penelitian dan Pengembangan Kesehatan: 198. http://labdata.litbang.kemkes.go.id/images/download/laporan/RKD/2018/Laporan_Nasi onal_RKD2018_FINAL.pdf.

Sya`Bani IRN, Sumarmi S. 2016. Hubungan status gizi dengan kejadian anemia pada santriwati di Pondok Pesantren Darul Ulum Peterongan Jombang. Jurnal Keperawatan Muhammadiyah, 1(1): 8-15.

World Heatlh Organization. 2008. World Wide Prevalence of Anemia 1993-2005, WHO Global Database on Anaemia. Geneva: WHO Press.

\section{Dokumentasi Kegiatan}
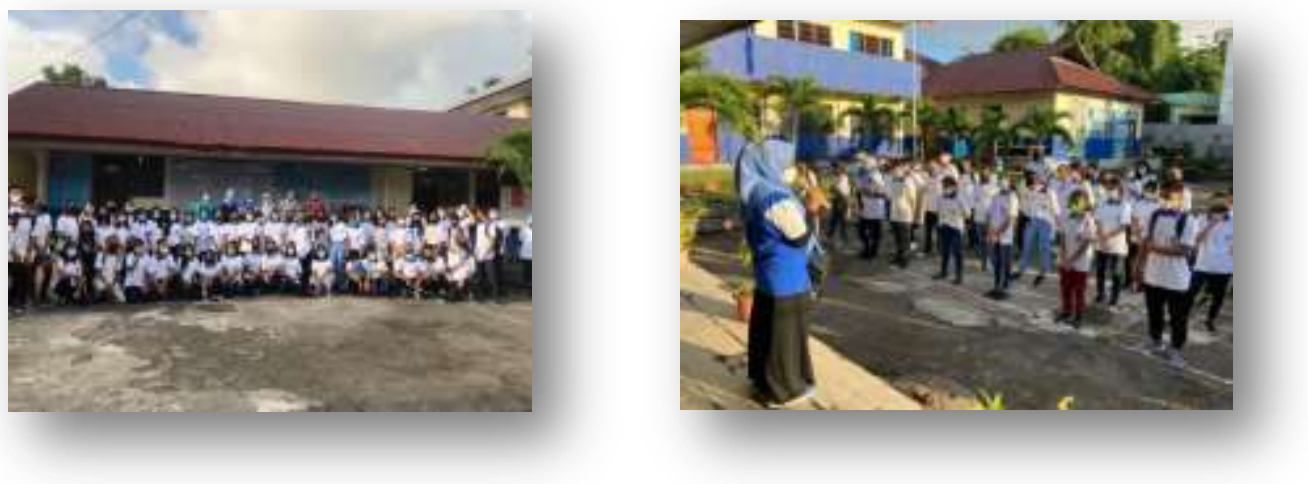